\title{
CERRAHLARIN YÜZYILI V
}

Jürgen Thorwald* Kazım Ergin*

\section{MEYVELER}

\section{«SUSAN}

O gece korkunç bir rüyadan uyanır gibi uyandım. Yanımda Susan'ın yattığı yer boştu. Bahçeye açılan camlı kapının ardına kadar açık olduğunu gördüm. Sebebini bilmediğim bir korku ile doğruldum. Ropdöşambrımı omuzuma alıp bahçeye çıktım. Gündüz gibi bir aydınlıkta sahile kadar olan düzlük uzanıyordu. Susan sadece incebir gecelikle bahçeyi sınırlayan sütunlardan birine yaslanmış ve elleriyle yüzünü kapatmıştı. Beni ancak arkasına kadar gittiğim ve ellerimi ona uzattığım zaman farketti. «Susan ne oldu? Allah asskına ne var?» diye fisıldadım. Fakat o sadece başını sallayarak "Yok birşey" demekle yetindi. Titrediğini hissediyordum. Onu kollarıma alarak eve götürdüm. Yatağa yatırıp üzerini örttüm. Üzerine eğilerek ısrarla sordum : "Susan, ne oldu? Herhalde birşeyler var, benden ne sakliyorsun?» Fakat benim bütün ısrarım boşuna idi. Kendini yeniden topladığını hissettim. Kendine hakim olmanın verdiği yüz ifadesi, çehresinden korkunun son izlerini de sildi. "Sana birşey söylemiyorum, çünkü söylenecek birşey yok» diye fisıldadı.

Bütün bu olanlar benim Afrika gezisinden döndüğüm ve biraz dinlenebilmek için bir Fransız balıkçı köyünde kiraladığımız bir evde 1880 yılı Mayıs ayının son günlerinden birinde geçiyordu. Ertesi sabah, zaten çoğu günlerde olduğu gibi, kırmızı güneş topunun ilk ışıklarının Mont. St. Michel'in duvarlarına ve merdivenlerine vurduğu ve kıpırtısız denizden yansıdığı günlerdeki gibi güzel bir sabaha uyandık. Susan dışarıda, terasta çay masasında oturuyor ve denizi seyrediyordu. Bana hala, alışık olmadığım derecede, soluk ve zayıf görün-

" Amerikada cerrah bir ailenin cerrah torunu

"* A.Ü. Tip Fakültesi Genel Cerrahi Profesörü

Geliş Tarihi : Mart 1, 1995

Kabul Tarihi : Mart 30, 1995 
dü. Günlük yaşamımızda hep birlikte olduğumuz insanlardaki değişiklikleri, nadiren erkence farkettiğimiz düşüncesi aklıma geldi. Dudaklarında benim için yeni olan ağrılı bir hal seziyor gibiydim. Boynu, yakasından pek ince bir şekilde çıkıyordu. Yoksa yanılıyor muydum? $\mathrm{Bu}$ belirtileri daha önce fark mi etmedim, yoksa bunlar evhamland1ğım şeyler miydi? Beni fark ettiğinde yüzüne hemen bir gülücük yayıldı. Birlikte geçirdiğimiz hayatımızın hiçbir sabahında eksik olmayan bu gülücüğü gayet iyi tanıyordum. Kahvaltı sırasında sadece peksimet ve biraz süt alması dikkatimi çekti. Ben yeniden «senin birşeyin var» diye israr ettim. "Kendini iyi hissetmiyor musun? Yoksa hasta mısın?» Gülümseyerek : «İnatçı sorularınla beni üzmesene. Dün akşam yemeği biraz fazla kaçırdım. Pekala biraz perhiz yapabilirim» dedi. «Ha... onun için mi dün gece» diyerek içimde büyük bir ferahlıkla zayıf, kahverengimsi elini tuttum. Büyük bir mutlulukkla okşadım.

Sonraki hafta içinde gelişen olaylardaki körlüğümü, bu güne kadar affedemedim. Susan'ın diyet denemelerini şaka ile izliyordum. Bu diyetle, ifadesine göre, Mont. St. Michel'deki fazla tıkınmasını tedavi ediyordu. Hafif hastalıklarında daima kendi formüllerine göre davranır ve bu tedaviyi de israrla ve inatla gerçekleştirirdi. Bunu bildiğim için benim yanılmamda bunun da payı oldu. Yine bundan dolayıdır ki, aynı hafta içinde Susan'ın o kendine güvenini bile zaman zaman kırabilen ızdırap veya korkularının belirtilerini de gözden kaçırdım.

Susan otuz yaşındaydı. Hayatının baharında bulunuyordu. Üç hafta geçmesine karşın hala püre ve peksimet yediğini görünce, ona yeterince çorba içtiğini, artık daha iyi şeyler yemesi gerektiğini söyleyip ikna ederek, sahilden birkaç mil güneydeki küçük bir motele gitmege razı ettim. Oraya, Paristen bile, yemeğe meraklı kimseler geliyordu. Orada benim ona özel olarak hazırlattığım çok yumuşak etler, sebzeler yemeğe ve çok hafif kırmızı şaraplar içmeğe başladı.

Birkaç hafta önce olduğu gibi, bu kez de gece yarısı uyandım. Fakat bu kez bir rüya sonucu değil, hafif bir gürültü sonucu uyanmıştım. Herhalde rüzgar camlı kapıyı çarpmış olmalıydı. Yanımdaki yastığa baktığımda yine o geceki gibi boş olduğunu gördüm. Yine o zamanki gibi büyük bir korkuya kapıldım ve kalbim deli gibi çarpmağa başladı. Kalkıp dışarı fırladım.

Ay yine o akşamki gibi parlıyordu. Fakat bahçe boş ve terkedilmiş gibiydi. Bahçede, komşuların hayretle karşıladığı, bizim banyoya dönüştürdüğümüz küçük bir bina vardı. Bir süre sonra oradan öğür- 
tü ve kusma sesleri duydum. Kendimi suçlamağa başladım. Fakat Susan'ın derdinin ne olabileceğini düşünürken düşüncelerim değişik bir yöne saptı. Oğlumuz küçük Tom'un ölümünden yıllarca sonra, bastırılmıș kompleksimiz ve gizli arzularımız birdenbire su yüzüne çıkverdi.

Çok uzun zamandanberi, bütün boşa çıkan umutlardan sonra, yoksa Susan yeniden çocuk sahibi mi olacaktı? Bu düşünce beni etkisine aldıkça kalbimin çılgın atışları yavaşlamağa başladı. Uzun bir süre sonra Susan'ın hafif adımları duyuldu. Soluklarını duyuyordum. Yatağa girerken hafifçe içini çektiğini duyunca kalbim yeniden hızlı hızlı atmağa başladı. Artık bekleyecek ve susacak halim kalmamıștı. «Lütfen affet, bilmiyordum" diye fisıldadım. Birden irkildi ve "Sen uyanık mısın?» diyerek şaşırdı. Elini bulup öptüm ve «Evet uyanığım. Son günlerde kötü birşey yaptım. Söylesene bugün ilk kez mi yoksa daha önce......?». "Evet daha önce de oldu» diye cevaplayıp sanki derdini benden saklamağa çalışıyordu. Ben «yalnız diyet yemekleri yediğin zaman da oluyor muydu?" dedim. Susan "o zaman pek böyle değildi» diye fısıldadı. Peki bunun nedeninin bir bebek olduğu hiç aklına geldi mi?» diye sordum. Birdenbire bir sessizlik oldu. "Aman Allahım" diyerek bütün vücuduyla bana doğru kaydı. Yüzü çok yakınımda idi ve ay ışığında yaşlar akan gözlerini gördüm. Tekrar «Aman Allahım» diyerek hıçkırıklarla sarsılmağa başladı. Ben bunun sebebinin sevinç, yalnızca sevinç olduğunu, bu göz yaşlarının bundan olduğunu düşündüm.

Sahilde kiraladığımız evde oturalı beri, Susan altı haftada bir Rennes'e gidiyor ve alışveriş yapıyordu. Bu alışverişleri daima tek başına hallediyordu. Bu kez de gitmeğe hazırlanınca, ona eşlik etmeği istedim. Fakat yalnız gitmekte ısrar edince ve bütün yüzünü kaplayan bir tebessümle iyi olduğuna, kendini çok iyi hissettiğine beni inandırınca daha fazla üstelemedim. Ama gidince içime öyle bir huzursuzluk doldu ki, odalar arasında gidip gelmeğe başladım ve nihayet Susan'in yazı masasına oturdum. Sanki onun yokluğunda bu masa bizi birbirimize bağliyordu.

Uzun süre orada oturduktan sonra Susan'ın takvim yapraklarıyla oynamağa başladım. Birden 10 Temmuz yaprağındaki birkaç satır yazı gözüme ilişti. Belki de bu yazıları yakından bile izlemeyecektim ama, bir doktor adı gözüme çarpmıştı. Takvimi tamamen kendime çevirince «Dr. Vauban» yazısını okudum. Öteki, satırlar Rennes'te yapılacak 
alışverişin notlarıydı. Huzursuz bir gün ve huzursuz bir gece geçirdim. Nihayet ertesi gün öğleden sonra Susan geri döndü. Gözlerimi yüzüne dikmiştim. Sanki 'Dr. Vauban'a yaptığı ziyaretin hikayesi yüzünde yazılmış olacaktı. Susan koşarak boynuma sorıldı. Tıpkı batmakta olduğu denizdeki hayat kurtarıcı bir ada gibi bana sarılmıştı. "Seni bir daha bırakmayacağım, sensiz hiçbir gün, hiçbir saat geçirmek istemiyorum. Güneș doğduğu sürece, her gün ve her saatin tadını seninle paylaşacağım" diye fisıldadı.

Akşam, başını koluma yasladığında : «Bu yıl New York'a erken dönelim. Biraz hasretlik çekiyorum galiba» dedi. Herhalde çocuğunu orada doğurmak istiyordu. Yoksa başka birşey mi vardı? «Eğer istiyorsan hemen gideriz" dedim. Bunu söylerken önerime ne kadar candan razı olacağını bilmiyordum. "Evet lütfen, lütfen gidelim» dedi. Ben «Öyleyse yarın Paris'e gidip, her şeyi ayarlayayım. Ondan sonra bir iki hafta içinde seyahate çıkabiliriz» dedim. Ama yine de ben Paris'i değil, Rennes ve Dr. Vauban'ı düşünüyordum. Paris'i bir bahane olarak öne sürmüştüm. Rennes'e gidip Vauban'ı ziyaret edecek re Susan'ın dưrumunu soracaktım. Ertesi sabah Susanı hiç şüphelendirmeden yola çıktım. Rennes'te trenden inip bir araba tutarak, beni Dr. Vauban'a götürmesini söyledim. Vauban hastalarını ziyarete gitmişti ve ben iki saat kadar dönmesini bekledim. Nihayet döndüğünde beni hemen kabul etti. Eski pratikten yetişme, aynı zamanda Paris'te klinik eğitimi görmüş bir hekimdi. Beni öyle ciddi bir yüzle karşıladı ki, huzursuzlandım. Yüzüme tuhaf tuhaf bakarak : "Çok cesur bir karınız var» dedi Ben "Evet cesurdur. Beni daima kendi sıkıntılarından uzak tutmağa çalışır. Size geldiğinden de haberim yoktu. Rastlantıyla öğrendim.» diye cevapladım.

Doğrularak «Öyleyse benim teşhisimden haberiniz yok mu?» diye sordu. Ben «Hayır. Bulantı ve fenalık nöbetlerinin farkına vardığımdan beri hamile olduğunu düșünüyordum. Dört yıl önce biricik çocuğumuzu kaybetmiştik».

O «Gebelik» diye söyledi. Sesinde hakiki bir çaresizlik var gibiydi. «Anlıyorum. Karınız genç olduğu için en önce bu düşünce aklınıza gelmiş. Ama buna rağmen...» durakladı. Ben : «sizi anlamıyorum, ne demek istiyorsunuz?» diye sözünü kestim. «Karmız durumunu sizden daha iyi değerlendiriyor. Acı da olsa şunu söylemeliyim ki, bir hamilelik söz konusu değil. Size karşı çok açık olmak zorundayım. Zaten karınız da kendine karşı çok açık olmamı o kadar ısrarla istedi ki, sonunda 
yenildim. «Ben sessizce dinliyordum. O devamlı «Karınızın bir mide rahatsızlığı var. Pilorda, yani midenin çıkışında, bir ur var. Ancak nadir vakalarda ele gelmesine ragmen onda hisseciliyor. Zaten bana gelmeden önce kendisi elleyerek farketmişti. bu ur son haftalarda çok çabuk büyümüş olmalı. Mide çıkışını o kadar çok daraltmış ki, ancak hafif ve sulu gidaların duodenuma geçişine izin veriyor». Dr. Vauban biraz durakladı. Benim konuşmaktan aciz olduğumu görünce devamla : Palpasyon ve bütün öteki klinik bulgulara göre, ne yazık ki kötü huylu bir tümör olduğunu kabul etmemiz lazım. Eğer iyi huylu bile olsaydı, temelde prognoz yine aynı olurdu. Bu halde ızdırap daha da uzun sürerdi. Hanımınız bilimin bu güne kadar onun hastalığına bir çare bulamadığının bilincinde. Onun için, sadece yurdunu hayattayken bir kez daha görmek tek arzusu. Herhalde bu arzusunu yerine getireceksiniz».

O anda üzerime çöken karanlıktan sıyrıldım «Size inanmıyorum inanmıyorum" diye haykırdım. O anda içimden kopan çllgın, vahşi bir çaresizlikti. Fakat bu isyan ve çaresizlik içinde Vauban'ın sözlerinin gerçek olduğunu seziyordum. İsyan içinde çırpınırken bile zihnimden mide cerrahisine ait bazı bilgiler sırasıyla geçmeğe başladı. "Pean" adı aklıma geldi. Profesör Pean, Pariste Hotel St. Louis, öteki daha az ünlü adlar, şehir adları, okuduğum veya henüz okumadığım bilimsel tıbbi makaleler ve en önemlisi Pean'ın bir makalesinin adı bir anda aklımdan geçti.

Vauban «Sayın meslekdaşım. Lütfen kendinizi toplayın» Ben zoraki bir gayretle : «Lütfen bu tașkınlığımı bağışlayın... Sadece sizden bir ricam daha var".

«Lütfen söyleyin». "Sizin gelmenizi beklerken Paris'ten Gazeteden Hopitaux sayılarını bekleme salonunuzda gördüm. 1879 yılına ait olanını bir gözden geçirebilir miyim?»

Bana hayretle bakarak : "Tabii. Her ne kadar şimdi üzerinde konuştuğumuz problemle ne ilgisi olduğunu bilmiyorum, ama o yıla ait saylar emrinize her zaman amadedir».

Vauban'ın evinden çıktıktan sonra, o zamana kadar farketmem gereken birçok şeyi görmeme engel olan bir perde gözümün önünden kalkmış oldu. Susan'ın annesinin otuzaltı yașında «bilinmeyen bir mide hastalığından, muhtemelen kronik dispepsi» den öldüğü düşüncesi şeytanca zihnime sokulup duruyordu. Ben ki, Susanla birlikte yaşıyor ve ailesinin geçmişini biliyordum acaba kör mü olmuștum? Sağa sola 
bakmadan, çevremi görmeden eski caddelerden geçerek şehrin sınırına ulaştım. Artık beni kimsenin görmeyeceği bir çalılığa cturdum. Orada Vauban'ın evinden alıp yanımda getirdiğim dergiyi açtım. Sayfaları çevirdim ve burada, küçük bir Fransız şehrinin dışında, bu inanılmaz atmosferde Hotel St. Loues,in ünlü cerrahı Jules Emile Pean'ın birkaç ay önce yazdığı «Mide urlarının gastrektomi ile çıkarılması" başlıklı makalesini okumaga başladım. Bu makaleyi, daha önce de diğer birçok makale gibi şöylece bir görmüş ve ileride daha iyi okumak üzere evde bırakmıştım. Fakat başlığını ve kısmen de içeriğini öyle derin bir şekilde hafızama yerleştirmiştim ki, Vauban bana ölümcül teşhisini bildirdiğinde hemen hatırlamıştım.

Pean şöyle yazıyordu. : «Midenin kötü huylu tümörleri oldukça slktır. Fakat bu tümörlerin sonu ölümcül olduğu için, klinisyenlerce pek iyi bilinmezler. Cerrahi bir müdahale pek söz konusu olamaz. Biz de tümörü çıkaracak herhangibir müdahaleye hep karşı olduk».

Fakat bir sonraki cümlede Pean, bu bariyerin üzerinden yaptığı ilk sıçramayı bildiriyordu : "Pilorun (mide çıkışının) tamamen daralması sonucu haftalardan beri mideye giren hiçbir gıda maddesinin oniki parmak barsağmna geçemeyişi sonucu, hastanın çaresizlik içinde arzusu bizim yukarıdaki ilkemizi değiştirmemize neden oldu. Beş günü aşkın süredir hasta bütün gıdaları, hatta sıvı gıdaları bile ağzına alır almaz kusuyordu. Bu korkunç rahatsızlığı onu o dereceye getirmişti ki bu durumundan onu kurtarmayı hiç olmazsa denemezsek intihar edeceğini söylüyordu. En hafif bir yaralanmayı veya çok hafif bir peritoniti yenmeye kuvvetinin yetmeyeceğinden korkuyorduk... Ama midesine beslenme fistülü yaptığımız birçok hastada şaşılacak bir düzelmeye şahit olmuştuk..., ve nihayet hastanın, hasta ailesinin ve doktorunun arzularına boyun eğdik. Ameliyat 9 Nisan 1879 da Frere St. Jean de Dieu hastanesinde yapild.

Beş parmak eninde göbeğin biraz solundan yukarıdan aşagıya bir kesi yapıldı.

Süratle gözdengeçirmekte olduğum Pean'in bildirisi böyle başlyor ve devam ediyordu : "Karın açıldığında midenin hipertrofiye olup bütün karın boşluğunu doldurduğunu gördük... Midenin pilor kısmını biraz orta hatta doğru çektik... Bu çekim tümörü ortaya çıkardı. Tümörün merkezi pilordu ve tümör gerek mideye, gerek oniki parmak barsağına doğru yayılmıştı... Sucuk gibi bir görünümü vardı ve altı santimetre çapındaydı. Sindirim kanalının bu kısımda tamamen kapa- 
lı olduğunu belirlemek zor değildi...Mideyi ve barsağı tümörün üstünden ve altından kestik. Midenin içinde bulunan sıvının karın boşluğuna dökülmesini önlemek için mideyi kesi yerine yakın uzun bir trokarla ponksiyone ettik. Gerek belli bir basınçla sıkılmasıyla, gerek hastanın narkoz etkisiyle öğürmesiyle mide tamamen boşaltıldı. Asistanlarımızın mahareti dolayısiyle, karın boşluğunun temizlenmesine gerek kalmadan karın yarasını dikerek kapattık. Ameliyat ikibuçuk saat sürdü». ilk okuduğumda üzerinde durmadığım bir konu şimdi okurken aniden aklıma geldi. Pean'ın bildirisinin eksikleri vardı; örneğin mide ve barsağın nasıl birleştirildiğine ve nasıl bir dikiş kullanıldığına ilişkin birşey söylememişti. Bildiri şöyle devam ediyordu: «Hasta örtüldü ve sicak tutuldu. İkinci günün sonunda kendisine yiyecek verdik. Hasta bunu iştahla yedi ve büyük bir kısmını kusmadan muhafaza etti. Üçüncü gün de aynen devam etti. Sadece yemeklerin bir kısmını biraz safralı olarak kustu. Safralı oluşu mide ile sindirim kanalının aşağı tarafındaki bağlantının tutuğu ve sindirim sisteminin devamlılığ1nın sağlandığının bir belirtisi idi. Nabız bu günlerde zayıf olarak bulundu... Bu zayıflığın açlıktan dolayı olduğunu düşündük ve bunun için Dr. Brochim ve Dr. Bernier bir kan transfüzyonu yaptılar. Hastanın rengi biraz düzeldi... Nabız ertesi gün yine çok zayıf olduğu için bizim arzumuz üzerine Dr. Bernier ikinci bir transfüzỹon yaparak 80 gram kan verdi.

Mümkün olduğunca besleyici olan sıvı gıdalar ağızdan ve rektumdan verildi ve hasta çıkarmadı... Dördüncü günü beşinciye bağlayan gece yeni zayıflık semptomları görülme şanssızlığına ugradık ve sabaha doğru üçüncü bir transfüzyona karar verdikse de uygulayamadık. Gözümüzün önünde açlıktan zayıflıktan öldü... Eğer bir otopsi yapabilseydik, çok öğretici olacaktı. Acaba... Midenin dikişleri sidirim faaliyetine mi uğramıştı. Büyümüş olan mide tekrar kendini toplamış mıydı? Bunları saptamak mümkün olacaktı. Fakat bizim bütün ricalarımiza karşın aile otopsiyi kabul etmedi.

Benzer durumlardaki mide ameliyatlarının yanında olmamamıza karşın, birçok deneyimli cerrahın bu konudaki girişimini de reddetmeyeceğiz. Kanımız odur ki eğer hastalık sadece pilorda ise ve ölüm, açlıktan dolayı olacaksa bu gibi durumlarda herhalde haklı olarak... Fakat bu gibi durumlarda da böyle ağır bir ameliyatı kaldırabilmesi için hastaların yeterli gücünün bulunması gerekir». 
Şu halde Pean, açık seçik olarak, eğer bir hasta yeterli gücü varken erkence ona gelmişse iyi bir sonuç olabileceğini umduğunu yazmaktadir.

Peki Susan'm durumu nedir? Susan henüz erimiş ve çökmüş değil. Eğer Pean'a ümit verecek bir hasta varsa, o da Susan olmalı. O halde durum tam anlamıyla umutsuz değil.

Paris'e gidecek oluşumu kaderin iyi bir işareti olarak gördüm. Oraya gidecek, Pean'la görüșecek ve hakikaten gerekli olursa Susan'ı ameliyat edip edemiyeceğini öğrenecektim.

O zamanlar Jules Pean adı herkesin bildiği bir addı. Cerrah olarak ünü Fransa sınırlarının dışına taşmıştı. Fransa'nın en aranan cerrahı idi. Pean'in 1864 yılında Wells'i örnek alarak, bir yumurtalık tümörünü ilk kez Fransa'da ameliyat etmeyi göze almasi, Fransa'da onu ünlü bir cerrah yaptı. Daha önce de 1862'de kanayan ameliyat yaralarında makas şeklinde damar penslerini kullanmış ve bu da insan vücudunun bol damarlı ve çok kanayan iç kısımlarında kanı durdurmak için çok mükemmel bir cerrahi buluş olmuştu. Ayrıca uterus tümörlerinde tümörlerin veya tüm uterus'un karm duvarını açmadan vajina yoluyla çıkarılması yöntemini bulması, onun tartışmasız ününü perçinlemiştir.

Yillar önce Pean'm St. Louis hastanesinin daima tıka basa dolu ameliyat salonunda birkaç ameliyatını seyretmiștim. Ameliyathaneye girişi her zaman büyük gürüItü ve alkışlarla karşlanıyordu. Aklımda kaldığı kadariyle orta boylu, fakat genis ve iri yapılı koyu parlak gözlü bir zattı. Büyük iri elleri, sağ elinin bir parmağının ankiloze olup sertleşip kullanılamamasına karşı teknik birmaharetle ve hatta büyük bir virtüozite ile çalışırdı.

Oraya vardığımda hava kapalı idi. Geceyi otelimde hemen hemen uykusuz geçirmiştim. Pencereden baktığımda bulutların açılıp tüm Paris üzerine çöktüğünü gördüm. Sağnak halinde boşalırcasına bir yağmur yağıyordu. Ümit ile ümitsizlik arasında bocaliyordum. Cumartesi günlerinin hala St. Louis hastanesinde Pean'in ameliyat günleri olduğunu ögrendim. Onu hemen görmem gerekiyorsa orada buluşabilecektim.

Hemen bir araba ile hastanenin bulunduğu kenar mahalleye hareket ettim. Kapıcıdan öğrendiğime göre ameliyata başlamıştı bile. Ameliyathanenin yolunu biliyordum. İçeri girdiğimde, yine pürdikkat ameliyat seyreden birkaç yüz kişi gördüm. Kendime yol açarak önlere 
geçtim. Pean hala o eski masa başında asistanıyla birlikteydi ve kanserli bir kadının memesini elindeki bistüriyle çepeçevre kesmekle meşguldü. Moda olduğu gibi yalnızca bıyıkları ile çenesini sinek kaydı tıraş etmiş, bakımlı favorileriyle yarı hastaya, yarı seyircilere dönük durmakta idi. Şık bir frak giymiş, siyah papyon takmıştı. Sadece göğsüne bir yemek peçetesi gibi peçete takmış, bunu yeleğine iliştirmişti. Peçetenin örtemediği yerler ve keza gömleğinin manşetlerinin kan içinde olduğu ğörülüyordu. Karbol kullanımı yarım yamalak ve ameliyat salonu az temizdi. Her keside hasta inliyordu. Kendilerine sira gelmesini bekleyen ve orada bekletilen iki hasta, bu ameliyat gösterisini görmemek için başlarını yan tarafa çeviriyorlardı. Bunları farkettiğim anda içim sızladı ve Pean'ın bende eskiden bırakmış olduğu önemli imajda bir değişiklik olduğunu üzülerek hissettim. Bugünkü gözlerle baktığımda bendeki değişimin doğal olduğu inancına vardım. Bugün yıllarca önce mesleği ve tarihi öğrenme arzusu içinde Pean'm ameliyathanesine giden bir gencin gözleriyle bakiyordum cerrahlara. Kendi karımın ölüm kalım saveşmdaki korku beni buralara sürüklemişti. İçimi kötü bir duygu kapladı. Pean'ın sanatkarca hareketlerini poz yapan bir insanın hareket'eri gibi görüyordum. Ellerinin ve aletlerinin ustaca kullanımı, yüzüne sanki aşırı bir kibirlilik gibi yansıyordu. Yüzündeki soğukluk, ancak soğuk bir kalbin işareti olabilirdi. Öyle ki,o kalp için sadece ameliyat önemliydi. Ameliyat olanın kaderi sanki o kalbi hiç ilgilendirmiyordu.

Sargıyı asistanı Collins'e bırakıp sonraki ameliyata geçti. Bu bir şeker hestasıydı ve bacağı ampute edildi. Kesik ayağı Pean bir köşeye fırlattı. Orada biraz evvel çıkarılan memeden başka, çıkarılmıs başka organlarda bulunuyordu. Daha sonra bir dudak kansari ve boğulmuş bir fitık ameliyatını tamamladı ve sonuna bir suni anüs yaptı. Tüm bu ameliyatlar sırasında gövdesinin duruşu hiç değişmemişti. Yüksek alınlı ve mağrur burnu ile yüzü tamamen hareketsiz kalmıştı.

İki saatin sonunda Pean çevreyi parlak gözleriyle süzüp, yeleğinden peçeteyi teatlar bir hareketle çıkarıp, kısaca «baylar, bugünlük bu kadar» dediğinde ve hemen dişarıya çıkınca bendeki şaşkınlığı ve içimde uyanan savunma duygusunu anlatmam mümkün değil. Sanki uyuşmuş gibiydim ve Pean'in alkışlayan öğrencilerin arasinda kalakalmıştım. Gördüklerim ve duyduklarım içime yığılmıştı. Daha da çok, beni buraya getiren, çıkıs yolu olmayan ve Pean'a gitmeten başka çare olmayan yük içime oturmuştu. Güçlükle içimdeki fena hisleri ve kara korkuyu atabildim ve aceleyle çıkışa yöneldim. Fakat kapıya geldiğim- 
de, Pean muhteşem bir çift atl araba ile oradan uzaklaşmakta idi. Korkuyla kapıcıya Dr. Pean'ın nereye gittiğini ve ona nasıl ulaşabileceğimi sordum. Kapıcı, Pean'ın şimdi özel hastalarını ziyaret etmekte olduğunu söyledi. Eğer şansım varsa, ileriki saatlerde özel ameliyatlarını yaptığı Convent de la Sante'de onu bulabilirmişim. Hemen yola koyuldum. Yağmur altında bindiğim arabada hep gözlerimin önüne Pean'ın ve ameliyathanesinin hayali, onun artistik cesur yöntemleri, yüzünün soğuk ve kibirli hali geliyordu. Paniğe kapılıyordum. Oradan kaçıp gitmek, Susan'a yazılmıș iyi ve kötü günleriyle kadere teslim olmak gibi bir düşüncenin neredeyse, uygulama sınırına geliyordum. Sante bulvarında arabadan inip Pean'la görüşmek için kapıcıya başvurdum.

Bütün ünlü doktorların hizmetlilerinde adet olan bir küçümseme ile, bana bugün Pean'm artık hiç kimseyi kabul etmeyeceğini bildirdi. Ziyaretimi pazartesiye kadar uzatmamayı iyice aklıma koyduğum için, onu geçerek içeriye girdim. Kapıcı omuz silkip giderken ben de manastır avlusuna benzeyen giriş koridorunu arşınlamağa başladım. Yarım saat geçmişti ki caddeden atların nal seslerini duydum ve Pean içeri girdi. Beni soğuk ve aşağılayıcı bir tavırla süzdü. Benim kararlı bir biçimde ve onun mağcur halinden etkilenmeden kalkıp ona doğru gittiğimi görünce "Monsergör biz burada Paris'te Amerikalıların kaba adetlerine alıșık deği iz. Zannederim size söylemişlerdir... "Ben sözünü keserek: «Eğer bir insanın hayatı söz konusu ise ve ona yardım edebilecek tek insan siz iseniz, ben de açıkça söyleyeyim, bizim kaba adetlerimiz bile geçerlidir».

Bilmiyorum benim kararlılığım mı, yoksa Fransızca konuşmam mı yoksa onun yardım edebilecek tek kişi oluşunun gururunu okşaması mı etkili oldu? Bir an bana kararsızlıkla baktı. Sonra kapıcıya dönerek "Peki, beyi kabul odasına alın", sonra bana dönerek "Beni orada bekleyin, fakat ne anlatacaksanız özetleyin» dedi.

On dakika sonra geldi. Susan'la ilgili her şeyi anlattım ve Paris'te Susan'ı muayene etmesini ve eğer Vauban'm teșhisini doğrularsa, Susan'da da mide çıkışındaki hastalıklı bölümün çıkarılması ameliyatını tekrarlamasinı rica ettim. "Gazette des Hospitaux'taki bildirinizi dikkatle okudum. Sizin bu ameliyatınızın karımı kurtaracak tek yol olduğuna inanıyorum. İşte sizin de şart koştuğunuz gibi, henüz kuvvetten düşmemiş bir hasta. Eğer uygun buluyorsanız birkaç gün içinde karımı Paris'e getireyim. Masrafın ve paranın hiç önemi yok" dedim. 
Sözümü yüksek sesle kesti : "Herşey para ile satın alınamaz. Mesale bu sizin bahsettiğiniz şey gibi». "Yani bu benim eşimi ameliyat etmeyeceğiniz anlamına mı geliyor?» Sırtını bana döndü ve o muktedir beyaz ellerini arkasında kavuşturup : «Evet öyle» dedi. «Peki niçin? hangi nedenle?» diye atıldım. Ancak birkaç dakika sonra yüzünü bana döndü: «Evet bunun nedeni size söyleyeyim». Her sözü yavaş ve üzerinde dura dura söylüyordu. «Ben bu ameliyatı hastanın yakınlarının israrlı zorlamaları sonucu yaptım. Eğer makalemi dikkatli okuduysanız bunu bilmeniz gerekirdi. Mide çıkıșındaki tümörlerin cerrahi olarak çıkarılması ameliyatının tekrarlanabilmesi için, yıllar sürebilecek çok zahmetli araştırmaların yapılması gerekli. Mide ile barsağın birleştirilmesinde en güvenli dikiş yönteminin bulunabilmesi için sayısız hayvan deneylerinin yapılması, bu dikiş materyalinin ipek mi, katgüt mü, yoksa metal mi olması gerektiğinin sayısız hayvan deneyleriyle kanıtlanması gerekli. Böyle bir ameliyatı hastanın kaldırabilmesi için, bu süre içinde bir başka beslenme yolu bulmak lazım. Pilorun çıkarılmasından sonra sindirim fonksiyonunda oluşabilecek değişiklikleri incelemek, midenin yeni bir pilor yapıp yapmayacağını ögrrenmek ve nihayet ve belkide en önemlisi kötü huylu bir tümörün tekrarlamaması için, ameliyata kadar ne kadar bir zaman geçebileceğini veyahut bunun mümkün olup olmayacağını bilmek lazım. Asistanlarım bu deneylere başladılar. Onların deney sonuçları açık kurallar getirinceye kadar piloru çıkarma ameliyatını tekrarlamayacağım».

Israr edebilmek için içimden nedenler arıyordum. Pean kuru bir sesle «Üzgünüm» deyip kapıya yönelerek randevumuzun bittiğini ima eder gibiydi. Hemen yolunu kestim : «Dikiş yöntemlerinin böyle sorun yaratacağını sanmıyorum. Kırkbeș yıl kadar önce hemșehriniz Lembert, barsak ameliyatlarında dıs seroza tabaksının sırt sırta getirilmesiyle iyi bir kaynamanın ve yara iyjleşmesinin oluşacağı bir dikiş şekli bulmuştu. Şimdi bu yöntem mide - barsak dikişinde geçersiz mi olacak? Şimdi Heidelberg'de çalışan Czerny de.» Devam edemedim. Sözümü yüksek sesle ve bu kez heyecanla kesti : "Size yeniden söylüyorum. üzgünüm, ama karınızı ameliyat etmeyeceğim.»

Şimdi onun ameliyatlarındaki dikişlerde büyük hata yapmış olduğunu düşünüyorum. O öteki ülkelerdeki gibi, örneğin Czreny dikiş yöntemine önem vermemiști. Ayrıca mide ülseri ameliyatları yıllardan beri yapılmaktaymış; ama benim de haberim yoktu. Pean de bilinçli veya bilinçsiz bunları görmemezlikten gelmişti. Herhangi bir ön çalış- 
ma ve hazırlık yapmadan, ilk büyük mide ameliyatına kalkışmış ve bu alanın henüz şöhret getirecek nitelikte olmadığını anlamıştı.

Kapıya doğru yürüdü ve açtı. Ben, bir an tereddüt ettim, sonunda soğuk bir veda ile ayrıldım.

Daha sonra da Pean'ı hic aramadım. Duygularıma dayalı ön yargılara varabileceğini yıllar çok gerilerde kaldıktan sonra bile, Pean'ın bendeki izlenimi, teknik virtüozitesine karşın hekim olmanın gerektirdiği insani yanının eksik kaldığı idi. Patolojik anatomi ve yara hastalıkları bilimierinin erken döneminde bazı cerrahi öncüleri gibi, o da ilerlemesini hastalarının hayatını hiçe sayarak sağlamış ve antisepsinin bulunuşuyla cerrahinin gittikçe daha insani bir çehre kazanmasina karşın, o tutumunu değiștirmemişti.

Pean'la karşılaşmamızın ertesi akşamı kaderin cilvesinden şaşırmış bir durumda yeniden sahile döndüm. Artık, Susan'a Amerika yolculuğumuzu hazırlamak için gitmediğimi, Doktor Vauban'ı bularak Paris'te Jules Pean'le görüştüğümü söyleyebileceğimi sanıyordum. Her yolculuk dönüşü olduğu gibi, Susan evin önünde beni karşılamağa çıkınca aniden irkildim. Birkaç günlük ayrılık bile, Susan'ın yüzündeki güneş yanığına karşı, onun ne kadar zayıfladığını farketmeme yetti.

Bana sarılarak «Ne zaman yola çıkıyoruz? Her şeyi hallettin mi?» diye fısıldadı. Gerçeği söylemekteki kararlılığım bir anda kayboldu. Doğrudan yalan söylemedim ama; «Bize haber verecekler. Önümüzdeki hafta Southampton'dan birçok gemi kalkacak. Fakat, kesin hareket zamanı, henüz belli değil» diye bir kaçamağa sığındım. Akşam güneşi altındaki terasta yemeğe oturduğumuzda, onun tabağının olduğu yer boștu. "Ben yemeğimi yedim. Sen geç kaldın. Bende çok acıkmıştım, affedersin» dedi.

Öyle mutlu görünüyordu ki... Hemen yanıma sokuldu, yemeğimi önüme koydu. Böyle olunca, ben de gerçeği söylemek cesaretini kendimde bulamadım, sustum. Belli etmemeğe çalıştım.

Fakat, daha sonra, ay ışığında başını koluma yaslayıp yattığında, soluk alış verișinin düzgün olușundan uyuduğuna karar verince usulca yana döndüm. Sağ elimi dikkatlica Susan'a doğru uzattım. Elimi değdirmeden uzunca bir süre bekledim. Hala çekiniyordum. İnce geceliği bana engel değildi. Elim farkedilecek kadar titriyordu. Kalbim hızlı hızlı çarpmağa başladı. Titrememi önlemek için bütün gücümü topladım. Nihayet çoktan muayeneyi unutmuş elimle palpasyon yap- 
mayı denedim. Dikkatle elimi bastırdığımda bile, karın duvarı gevşek olduğu için herhangi bir zorluk olmadı. Karın duvarı pek ince idi. Arayan parmaklarım göbeğin üç parmak üstünde hafif hareketli ve oldukça sert bir kabarıklık farketti. Büyük kısmı linea alba'nın solunda idi. Tümör bir çocuk yumruğu büyüklüğünde idi. Kalbim bir pençe içinde sıkılıyor gibiydi. Bütün vücudumu ter kapladı. Demek Vauban haklıydı. Daha ben bunları düşünürken Susan'nn sesiyle irkildim : «Demek ki her şeyi biliyorsun» diyordu. Ben : «Susan, Susan» demekten başka birşey yapamiyordum. Aniden bana döndü ve sağ elimi yakalayarak yanağına baștırdı : «Herșeyi bilmen iyi oldu. Artık neden eve dönmek istediğimi de anlıyorsun. Ne zaman gidiyoruz? dedi. "Bilmiyorum» diye itiraf ettim, "Ben Paris'e yolculuğumuzu ayarlamak için gitmedim. Böyle bir tümörü cerrahi olarak çıkarmayı göze alan Jules Pean'ı görmeğe gittim. «Susan : "Ama, onun hastası öldü.» Ben : Sen nereden biliyorsun?» diye hayretle sordum. Cevab1 . «Uzun zamandan beri senin karın olmam yetmez mi? Ben de biraz birşeyler öğrendim. Hastallğımı far kettiğimden beri okuyabileceğim her şeyi okudum. Hiçbir ümit olmadığını biliyordum. İçeride masamın üzerinde «Gazette des Hopitaux» duruyor. İşte onda Pean'in makalesi var, onu okudum. Benim ameliyat masasında ölmemi ister misin?»

«Tanıdığım bütün cerrahlara yazacağım. Pean'ın attığı ilk adımı tekrarlamalarını ve onun yöntemini geliştirmelerini isteye ceğim. Biz inatla uğraşırsak sen yaşayacaksın Susan”.

Ve inatla uğraştık. Ben bugün biliyorum ki, Susan bu işe hiç inanmadı. Surf bana olan sevgisinden dolayı bu işlerle uğraştı. Hayatım değişmişti. Tüm zamanım yazı masası ile kapı arasında geçiyor, ya mektup yazıyor, ya telgraf dağıtıcısını bekliyordum. Son yıllarda tanıdığım ve halen kliniklerinde çalışmakta olan bütün cerahlara yazdım. Almanya'ya Avusturya-Macaristan'a, İtalya'ya, İsviçre'ye, Fransa'ya, Ingiltere'ye ve Rusyaya yazdm. Ayrica Amerikaya da yazdım. Peanın ilk ameliyat yönteminin kopyalarını bütün dünyaya yolladım. Onlardan istediğim, Pean'ın göze alamadiğını daha iyi şekilde tekrar etmiş olmaları ve hastalarının bu ameliyatı talep etmiş olduğunun bildirilmesiydi.

Bunlardan elime gelebilen cevaplar; ya imkansiz ya da bu yöntemin geliştirilmesi için çok zamana ihtiyaç olduğu şeklinde idi. Almanya'dan bir de doktora çalış̧ması yollanmışdı. Karl Theodor Merrem adlı bir tıp öğrencisinin 1810'da Giessen Üniversitesi'nde yapmış ol- 
duğu bir çalışmaydı. Merrem ilk aşamada, üç köpek üzerinde yaptığı çalışmada hastalıklı olan mide çıkışını mideden ayırmanın daha sonra da mide ile oniki parmak barsağı arasında yeni bir geçiş yapmanın mümkün olduğunu göstermişti. Ameliyat edilen ilk köpek ameliyatan sonra ondokuz gün yaşamıştı. İkinci köpek 47 gün yaşamış, ama 47. günün sonunda tam sağhỉklı iken çalınmıștı. Böylece Merrem onun durumunu izleyememişti. Fakat tıp bilim adamlarn Merrem'e gülüp geçmişlerdi. Aradan geçen yetmiş yılda da Merrem'in deneyleri unutulup gitmişti.

Birkaç gün sonra da Viyanadan bir mektup aldım. Gönderen genç asistan Johannes Von Mikulicz idi. Mikulicz, Avrupa'nın en meşhur ve becerikli cerrahi Theodor Billroth'un asistanıydı. Mikulicz ile 1879'da Londra'daki Kings College Hospital'de Lister'in yanında tanışmıştım. Bu nedenle ona da mektup göndermiştim. Şimdi Viyana'dan bana ilk cevap veren o olmuştu. Merrem'i ilk doğrulayanda o oluyordu ve yazısında Billroth'un eski asistanlarından Gussenbauer ve Winiwarter'in altı yıl önce Merrem'in deneylerini tekrarladıklarını ve köpeklerde mide çıkışının cerrahi olarak çıkarılmasının mümkün olduğunu ve köpeklerin hayatta ve sağlıkīı kaldıklarını belirlediklerini yazıyordu. Hatta aynı sıralarda, Czerny'nin insanlarda midenin tamamen çıkarılabileceği tezini savunduğunu ve asistanları Kaiser ve Scriba'nın bunun üzerine köpeklerde pilor ameliyatları yaptıklarını da ekliyordu. Hayvanlardan birisi bu zor ameliyatı oldukça iyi tolere etmiş ve beş yıl süreyle sağlıklı yaşamıștı. Mikulicz devamla, Billroth'un da bu deneylerden sonra insanlarda hastalıklı pilorun çıkarılabileceğini düşündüğünü ve ön çalışmalarm sürdürüldügüunü bildiriyordu. İnsanlarda böyle bir ameliyatın yapılması bir zaman sorunu idi ve belki de aylar, hatta haftalar söz konusu idi.

Mikulicz'den gelen mektubu aldığım günü pek hatırlamıyorum. 1880 Ekim ayı bitmiș ve sahilde çok güzel bir sonbahar hüküm sürmekte idi. Mikulicz'in mektubu elimde olduğu halde, bahçeyi geçerek eve doğru yürüdüm. Pencerenin önündeki bir divanda dinlenmekte olan Susan'a gittim. Susan mektubu okuduktan sonra, uzun süre yüzüme baktı ve o ince eliyle geri verdi. Hiçbirşey söylemedi, sadece gözlerinde bir iki damla yaş belirdi. Bu gözyaşlarını ben sevincinden zannettim. Onu öperek, hemen Vinayana mektup yazmak için yazı masasina yöneldim.

Her gün ümitle cevap beklemeğe başladım. Fakat, ilerlemeler hakkındaki sorularımın cevabı haftalarca gelmedi. Çok sonraları Mikulicz'in anlattıklarına göre, o zamanlar, o da bana bir ümit ulaştırabilmek için bir mucize beklemişti. 
Köyümüzün yalnızlığında ve kaybolmuşluğunda, gözüm ve kulağım hep Viyana'da iken 27 Kasım'da postacı bana. Königsberg'den bir mektup getirdi. Gönderenin adresi yerinde Königsberg Kraliyet Cerrahi Kliniği'nin Direktörü Karl Schönborn'un adı vardı. Çok az bir tanışıklığım olduğu için, aylarca önce birçok cerraha yazmış olduğum mektuplardan birini de ona göndermiştim.

20 Kasım 1880 tarihli mektubuna Schönborn şöyle başliyordu : "Weichsel yakmnnda Kulm'de, Dr. Ludwig Rydygier tarafından bir süre önce açlan özel bir cerrahi kliniğinde, dört gün önce bir ameliyat gerçekleştirildi. Bu ameliyat, aylarca önce sizin acilen bilgi sahibi olmak istediğiniz konuyu içeriyor. Daha önce Jena'da doçent olan, otuz yaşlarındaki Dr. Rydgier piloru tümüyle tıkayan kötü huylu bir tümörü çıkardı ve küçültülen mideyi onikiparmak barsağına dikti. Illk kez Pean tarafından yapıldığını bildiğiz türde olan bu ameliyat, bildiğime göre bu yöntemle yapılmıș ikinci ameliyat oluyor. Henüz işin ayrintılarından haberim yok. Ama Dr. Rydgier ameliyatin geliștirilmesinden ve geleceğinden son derece ümitli olduğunu bildirmiş. Bu konuda yakında size daha sağlıklı ve kesin bilgiler yazacağım».

Susan'ın odasına girdiğimde, onun yumruklarını karnına bastırıp, iki büklüm yana yatmış olduğunu gördüm. Daima hakim olduğu yüz hatlarında ızdırabın izleri vardı. Ben ona koşarak : "Senin ağrın var... Niçin bana seslenmedin? Susan... Susan niçin beni çağırmadın?» diye sordum. «Lütfen... Birşey sorma... Lütfen... Beni yanlız birak... Lütfen...» diyebildi.

Öyle yalvaran bir bakıșı vardı ki, istemeden de olsa odadan çıktım ve yukarı - aşağı gezinmeğe başladım. Dışardan ızdıraplı bir kusmanın seslerini duyuyordum ve beni bunun için dışarıya yolladığını anlamıştım. Temizliğini ve güzelliğini bozacak bu ezivetlere kimsenin tanık olmasını istemiyordu. Sonunda beni çağırdı. Pencerenin altında sakin ve gevşemiş olarak yatıyordu. Sanki yüzünde, sessiz teslimiyetçi bir olgunluk vardı. "Yanıma otur" deyince mektubu kendisine uzattım. «Lütfen, bırak» dedi. Bunları öyle ısrarlı ve öyle yalvaran bir sesle söylemişti ki, ısrar edemedim «Lütfen birak». Onun o zaman niçin öyle hareket ettiğini şimdi anlayabiliyorum. Hayatının gidişindeki yolun ne olacağının bilincine varmıştı ve düş kırıklığına uğramamak için, bir parça da olsa, umuda kapılmak istemiyordu. Sustum, ama ne o zamana kadar, ne de o zamandan sonra anlayamayacağım kadar Tanriya ve kadere isyan etmek istiyordum. 
Yarım saat sonra Königsberg'e Schönborn'a ve Kulm'e Rydygier'e birer telgraf çektim. Rydygier'e Susan'in hastalığını kısaca özetledim. Ona Susan'ı aameliyat etmeğe hazır olup olmadığını sordum. Telgrafı yolladıktan sonra, o günlerde elimizdeki ağrı azaltıcı tek ilaç olan morfin almak üzere eczaneye gittim.

Izdıraplı bir bekleyişle geçen sekiz günden sonra aynı gün içinde Kulm'den bir telgraf ve Königsberg'den bir mektup aldım. Titreyen ellerle açtığım telgraf şöyleydi : «Bulgularınıza ait kesin ayrıntıları ve hastanın şu andaki clurumunu bildirin. Bunlar olmadıkça bir karar verilemez... Rydgier". Mektup ise Schönborn'dan geliyordu ve Rydygier'in 16 Kasım'da yapmış olduğu mide ameliyatını içeren bir bildiri idi.

Önce Kulm'e bir telgraf daha çektim. Ama biraz yalan içeren bir telgraf olduğu için de, huzursuz oldum. İfademde Susan'ın durumunu biraz daha iyi göstermiștim. Pean'ı ziyaret ettiğim zamanki durumunu veya en azından ilk ağrı nöbetindeki halini yazmıştım. Ama ağrı nöbetinin tekrar etmemesi, Susan'ın biraz kendisini toparlamış olması ve günde iki kez benim kolumda bahçeye çıkıyor olması, beni durumunu daha iyi yazmağa yöneltmişti. Daha sonra bildiriyi okudum. Şöyle yazıyordu : «Mikotajewicz, 64 yașinda, annesi tüberkülozdan babası yaşlılıktan ölmüş. İki yıldan beri, karnındaki belirli ağrılar hiçbir zaman tamamen geçmiyor. Daha önce hiç mide şikayeti olmamış. Alkol alışkanlığı yok. Dört-beș haftadan beri kusmalar başlamış, kesin diyet ve morfine rağmen ağriları artmış. Uzun zamandan beri hasta günde sadece çorba ve birkaç peksimet yiyor. Buna rağmen, her gece, en geç saat 12 de şiddetli ağrılarla uyanıyor, bu ağrılar sabah saat 4 ila 6 ya, yediği her şeyi çıkarıncaya kadar sürüyor. Hasta gözle görünür derecede halsizleşti. Öyleki son zamanlarda ayağa kalkarken başı dönüyor ve yalpalıyor...»

Elimden kağıtları bıraktım. Rydygier'in yazdıkları korkutucu şekilde Susan'm içinde bulunduğu son duruma benziyordu. Rydygier şöyle devam ediyordu. : "Bu anamnez ve bulgular doğrultusunda hastaya sınırlı pilor kanseri (mide çıkışında kanser) tanısı koyduk. Ayrıca bu kanserin komşu organlara pek yapışık olmadığını ve belki de metastaz yapmadığını düşündük. Bundan dolayı da ameliyat endikasyonu koyduk. 16 Kasım 1880 tarihinde ameliyatı düşünüyoruz.» İçimde yeni ümitler filizlenmeğe başlamıştı. 
Rydygier'in bildirisi açık ve kesin idi. Kesiyi processus ksifoideustan göbeğe kadar linea alba'dan yapmıştı. Böylece peritona kadar inip peritonu açmıştı. Peritonun yara kenarlarını deriye tutturmuş ve karın içine doğru iyi bir görüş sağlamıştı. Tümör kesinin açıklığından görünmekte idi. Rydygier, tümörü çekebildiği kadar dışarı çekip, midenin arkasına ve pilor'a varabilmek için yeterince büyük ve küçük omentumu mideden ayırıyor, daha sonra kendi yaptığı bir «Elastik kompresör»ü mide çıkışından hasta kısmının hemen üstüne, midenin çevresine yerleştiriyordu. Bu kompresör «karbol solüsyonunda dezenfekte edilmiş» ve üzerine lastik geçirilmiş iki metal çubuktan oluşuyordu. Bunlar midenin önüne ve arkasına yerleştirildikten sonra, her iki ucu lastik bantlarla birbirine sıkıștırabiliyordu. Böylece midenin hasta kısmı ile, bütün yıkamalara karşın hala yiyecek maddeler bulunabilecek sağlam mide kısmı birbirinden ayrılmış oluyordu. Rydygier aynı biçimde bir kompresörü de oniki parmak barsağına koymuş, böylece hasta piloru, oniki parmak barsağından ayırmış ve kesit yapılınca barsak içeriğinin karna akıp iltihap odakları oluşturmasını önlemişti. Bu sonucu kompresörünü yerleștirmek bir hayli zor olmuştu. Çünkü oniki parmak barsağı oldukça derinde idi. Rydyggier son anda bütün özenine karşın parmağının duodenumda bir açılma meydana getirdiğini farketmişti : Hemen bu açı̆̆ı parmaklarıyla birbirine bastırmıştı. Barsak içeriğinin karna döküldüğünü sanmıyordu ama hasta piloru bir yandan mideden, öte yandan oniki parmak barsağından ayıracak önemli kesileri yapmadan önce ameliyat alanını iyice temizlemişti. Sonra bu iki kesiyi yapınca, mideyi çevreleyen sayısız arterlerden beklenmedik şekilde bol kanama olmuş, kritik dönemler yaşanmıştı. Rydygier, henüz Pean'ın kullandığı damar penslerini kullanmiyordu. Nihayet kan durdurulabilmişti ve Rydygier midenin ve onikiparmak barsağının yara kenarlarını yan yana getirmişti. Farklı büyüklükteki iki yara açıklığını birbirine uydurabilmei için mideden üçgen şeklinde bir parça kesmiş, yara kenarlarını Czerny dikişleriyle birbirine dikmiş ve böylece mide açıklığını barsağınkine uyacak biçimde küçültmüştü. Sonra her iki açıklığı birbirine dikmiş ve güvenlik açısından da üçgen bölümü mide dikişinin üzerine yeniden dikmişti. Böylece dikişten sızmaları veya midenin peristaltik dalgaları dolayısıyla dikişlerin gevşemesini engellemek istemişti. Rydygier önlem olarak altmış dikiş gibi çok sayıda dikiş koymuş ve dikiş hattını mide salgisının kirletmiş olabileceği düşüncesiyle iyice temizlemişti. Daha sonra, konulmuş olan kompresyon aletlerini kaldırmış ve yeni mide - barsak yolunu açmıștı. Karın yarasının kapatılması bir sorun 
yaratmamıştı. Lister pansumanı ile de, alan kapatılmıştı. Pean'ın bu ameliyat için harcadığı süre iki buçuk saat iken, Rydygier'in ameliyatı dört saat sürdürmüştü. Bu da Rydygier'in dikkatini ve özenini gösteriyordu. Hastaya birkaç kez Kamfre iğnesi yapılmıştı, çünkü kalbi yetmezlik gösteriyor ve dolaşımı gittikçe yavaşliyordu. Ameliyat bitiminden otuz dakika sonra narkozdan uyanmış ve kendisine biraz şarap verilmişti. Kendisi ameliyat hakkında sorular scrmuş ve sadece ameliyat bölgesinde biraz ağrı olduğunu başka bir rahatsızlık duymadığını söyleyerek rahat bir uykuya dalmıştı.

Buraya kadar okuduktan sonra ara verdim. Biliyordum ki, şimdi sonuca gelecekti, ölüm veya kalım sonucuna. Nihayet kesin bilgi sahibi olabilmek için yeniden okumağa başladım.

Fakat bu bilgi Rydygier'in özetlediği gibi kısa ve kesindi : "Gece saat 12 de Mikotajewicz huzursuz olmağa başladı, morfin yapıldı. Saat 2 ile 3 arasında göğsünde şiddetli ağrı ve büzülme, boğulma hissi şikayetleri ile kendini sağa-sola atmağa bașladı. Ayağa kalkmak istedi. Daha sonra kollaps'a girdi, arkasindan agoni gerçekleşti ve sabah saat 4'te öldü.

Kendi kendime "hayır... hayır» diye öyle yüksek sesle söyledim ki, hemen ağzımı elimle kapayıp, bu sözlerin Susan'a kadar ulaşmasını önledim. Schörborn Rydgier'in ameliyatin gelişmesi ve prognoz hakkında iyimser olduğunu yazmamış mıydı? Bu son olamazdı. Rydygier'in notunu yeniden elime aldım. Bakalım ne sonuca varmıștı? Ne karar veriyordu? Şöyle yazıyordu : «Karın boşluğunun otopsisinde önce bütün tümörün çıkarılmış olduğunu, karın organlarının hiçbirinde yayılım olmadığını belirledik. Periton iltihaplanmamıştı, düzgün ve parlaktı. Şu halde geriye iki olasılık kalıyordu : ya genel yetmezlik veya çok akut bir septisemi. Birincisi daha ağır basıyordu. Dikişlerin tutup tutmadığını saptamak için mideyi duodenumla birlikte kesip dışarı aldık. Duodenumu altından başlayıp, mideye su doldurduk. Dikiş çizgisi boyunca hiçbir sızıntı olmadı. Bu vakanın bizde uyandırdığı toplam kanı, bu ameliyatın bir geleceği olduğunu söyleme hakkını bize veriyor. İlk sonucun olumsuzluğu bizi korkutmamalıdır. Aslında, başlangıçta böyle zor bir ameliyattan başka bir sonuç bekleyemezdik. Her şeyden önce pilor kanserine daha erken dönemde tanı koymamız gerekiyor. Ardından da iyi ve emin bir ameliyat tekniği için yetişmemiz gerek". Rydygier'in bildirisini yere fırlattım. Sanki bu bildiri, benim hatamın suçunu taşıyordu. Saatler boyu odamda bir aşağı, bir yukarı gezindim durdum. Kâh yenilgiyi kabulleniyor, kâh kadere isyan 
edip kuduruyordum. Kulm'den çekilen bir telgrafı getiren ulak beni bu halde buldu. Telgraf şöyleydi : "Böyle ağır bir ameliyatın benim kliniğimden başka bir yerde yapılması ne yazık ki olanaksız. Ama hastayı kliniğime kabul etmeye hazırım». Telgrafı yere fırlattım. Artık bütün umutlarım bitmişti. Belki Susan, özel kiralanmış bir tren vagonu ile fazla hirpalamadan Kulm'e kadar gidebilirdi. Ama onu bu yolculuğa razı etmek çok zor olacaktı. Çünkü ona Kulm'de Rydygier'in aldığı kötü sonucu bildirmekten başka birşey yapamamıştım.

Birkaç gün boyunca yenilginin sınırlarında dolaştım, durdum. Sonra yeniden bir mücadeleye girdim. Beni umutlandıran bazı şeyler vardı. Susan'ın artık morfine gerek duymadığını saptamıştım, yemeklerini biraz daha fazla yediğini görmüştüm. Onu muayene ettiğimde hiç ses çıkarmamıştı. Tümörde herhangi bir küçülme tespit etmemiştim. Tümörde böyle «iyileşme» veya hiç olmazsa "duraklama» evreleri olabileceğini biliyordum. Birdenbire içimde, belki de bunun iyi huylu bir tümör olabileceği, tedavi için her ne kadar cerrahi bir girişim gerekliyse de, bana zaman tanıyacağı umudu doğdu.

$\mathrm{Bu}$ umut, beni bir kez daha Vinayana'ya yöneltti. Mikulicz'in cevap vermeyişi beni üzüyordu. $\mathrm{O}$, benim için Billroth'un kliniğine bir köprüydü. Sonraları öğrendim ki, son derece hassas ve son derece duygulu olan bu genç adam, henüz, cevabı olmayacak olan mektubumu açmayı bir türlü başaramamıștı.

Ocak ayı eziyet verici bir hareketsizlikle geçti. Aralık ayındaki iyiliğin devam etmesine öyle alışmıştım ki, Ocak ayının son haftasındaki değişikliklere dikkat etmedim. Susan'ın morfin gereksinimleri kontrol etmeyi bırakmıştım. Ancak Ocağın son günlerinde, birdenbire, hemen hiçbirşey yemediği dikkatimi çekti. Yeniden morfin kullanmakta olduğunu ve yedek morfinlerin hemen bittiğini farkettim. Ama Susan'a sormanın hiçbiranlamı yoktu. Çünkü durumu hakkında herhangi bir söz söylemiyor, konuyu başka yöne çeviriyordu.

Şubat'ın ilk günlerinde ancak biraz ayran içebiliyordu, başka da hiçbirşey alamıyordu. O zamanlar çok gözde olan peptonla suni beslenme için, Vauban'ı yardıma çağırdım. Susan bu işe ses çıkarmadan tahammül ediyor, sanki o uysal bakışıyla sadece sen istiyorsun diye katlaniyorum" diyordu. Vauban sessizce beni seyrediyordu. Onun yaşlı gri gözlerine bakamıyordum. Tam bu sırada kapı çalındı. Kapıyı açtığımda, bana bir telgraf uzatan postacı ile karşılaștım. Telgrafın imza yerinde Mikulicz adını okudum. Telgrafı yırtarcasına açtım. «Pro- 
fesör Billroth 29 Ocak'ta pilor tümörü olan bir hanım hastayı ameliyat etti. Hasta gayet iyi ve her geçen gün daha da iyiye gidiyor. Viyana'ya gelmeye hazırlanın».

$\mathrm{O}$ anda kalbimin gerçekten durduğunu sandığımı hatırlıyorum. Bütün vücudum sevinçten titreyerek Susan'in odasına koştum. Susan'ın önünde diz çöküp, kolumu boynuna doladım. Diğer elimle telgrafı yüzüne uzattım. Onu okumaya zorladım Bu sırada sürekli aynı sözleri tekrarliyordum : «Oku, Susan oku... Nihayet başardılar. Böyle olacağını biliyordum. Buna inanmıștım... Oku, lütfen oku...»

İsteksizce okudu... Sonunda gözlerini bana çevirdi. «Peki öyleyse Viyana'ya git» deyince ve sessiz bir tebessüme gömülünce içim sevinçle doldu. «Önce sen git. Orada ne yapıldığını iyice öğren. Eğer inanıyorsan... gelir beni alırsin ve birlikte gideriz" diye tamamladı. Ben «Ama sen ne yapacaksın? Yanında kim kalacak?» dedim.

"Maria kalır». Maria, eskiden bizim ev işlerine bakan kadındı. Sanki Susan'ın üzerine bir ataklık gelmiști. Bana yeniden : «Haydi sen git, çabuk git» diye söyleniyordu.

10 Şubat 1881'de, öğleye doğru Viyana'ya vardım. Mikulicz beni bekliyordu. Uzaktan onun zayıf, daima hareketli vücudunu ve sarı saçlarla çevrili ve hep solgun olan yüzünü farkettim. Beni içeri alırken her şeyi ayarladığını doğruluyordu. Bir saat içinde beni II. cerrahi kliniğine götürecek ve 29 Ocak'ta ameliyat edilmiș olan hastayı bana takdim edecekti. Hastanın bu kadar hızla iyileşeceğini, Billroth ve o hayal bile edememişlerdi. Ertesi gün öğlleden sonra da, Billroth evinde yarım saatliğine beni bekleyecekti. Daha sonra Mikulicz yapılan ameliyatı ayrıntılarıyla anlattı ve ben, kelimenin tam anlamıla, gözlerimi ve kulaklarımı dört açarak dinledim. Billroth'un asistanlarının köpekler üzerinde yaptıkları deneylerin gittikçe çok daha iyi sonuçlar vermesi üzerine, Billroth ameliyata uygun bir hasta beklemeğe başlamıştı. Fakat mide tümörleri hep «inoperabl» kabul edildikleri ve dahiliyeciler tarafından sadece ağrı kesicilerle tedavi edildikleri için, Billroth'un kliniğine pek az vaka geldi. İște bu vakalardan biri, Billroth'un 29 Ocak'ta ameliyat ettiği kırk yaşındaki sekiz çocuk annesi bir kadındı. Altı haftadan beri, yediği her şeyi kusuyor, sadece ayranla beslenmeğe çalışıyordu. Zayıflıktan iskelet haline gelmişti. Teşhis o kadar kesindi ki, Billroth pilor tümörünün ameliyatına karar verdi.

Billroth köpeklerde defalarca denenmiş olan yöntemi aynen uygulamağa karar verdi. Ameliyat sırasında hastalığın çok ilerlemiş ol- 
ması ve mide barsak ağızlarının birleștirilemeyeceği durumları için bile yardımcı çözümler düşünülmüştü. Röntgen ışınlarının bulunmasindan çok önce yapılacak olan bu girişimde, $\mathrm{O}$ önüne çıkacak tüm süprizlere kendini hazırlamıştı. Ameliyattan önce hastanın midesini yıkatmıștı. Ameliyattan sonra hastayı suni olarak beslemek için, pepton lavmanları da hazırlatmıştır. Çünkü, hasta eğer uzunca süre hayatta kalırsa, midenin ne şekilde davranacağını henüz dünyada kimse bilmiyordu. Billroth antisepsi altında ameliyatını yapıyordu. Her şey bir kronometre düzeninde gerçekleşiyordu. Sanki burada, ilk öncüleri tarafından başarılamamış yeni bir ülke bulunuyormuş gibi her şey aşırı bir düzen içinde oluyordu.

Mikulicz bunları anlatırken, ben Billroth'un amelivattaki her çalışmasını Pean ve Rydgier'inkilerle karşılaştırıyordum. Billroth Rydygier'den daha iyi bir ameliyat kesisi seçmişti; hele Pean'ınkinden çok çok daha iyisini. Daha başka dikiş tekniği kullanmıştı ve damarların bağlanmasını hemen hiç kan kaybı olmadan gerçekleștirmişti. Bunlar hep çok iyi planlanmış bir ameliyatın göstergeleriydi. Fakat genel olarak bakıldığında Billroth'un ameliyatı Rydygier'inkini hatırlatmaktayd. Billroth midedeki kesik ağızı bir «okklusion" dikişiyle barsaktaki kesik ağız genişliğine kadar küçültmüş, sonra birbirine ağızlaştırmıştı. Rydygier'in ameliyatının dört saat sürmesine karşılık, Billroth'un ameliyatı için, narkoz başlangıcından karnın kapatılmasına kadar, bir buçuk saat yetmişti.

Billroth'un kliniğine doğru giderken kendimi güven ve ümit dalgaları üzerinde yüzüyormuş gibi hissettim.

Mikulicz «Hasta onüç gün önce ameliyat edildi. Ameliyattan sonra hiçbir zafiyet göstermedi. Ağrısı ve kusması da yok. Önce kendisine biraz buz, daha sonra da her yarım saatte bir bir çorba kaşığı ayran verdik. Bunlara kolayca dayandı ve hiçbir yakınması olmadı. Birkaç gün sonra da ilk kez normall bir sindirim yapabildi. Hastayı saat saat izledik. Geceleri birçok kez korku ile uyandım. Herhangi bir şey olacağı, midenin hareketleri ile dikişlerin gevşeyeceği veya dokuyu keseceği, peritonit veya ateş olacağı korkusuyla. Fakat hiçbir şey olmadı. Doğrusu bu bir «mucize» gibi. Biz de bunu hep bir mucize olarak kabullendik...»

Bugünkü durumla karşılaștırdığımızda, gürültülü ve pis kokulu bir hastanenin bir koğuşunun kapısında durmakta idik. Billroth, yaşadığı bu büyük gelişmeyi işte bu binada gerçekleştirmişti. Mikulicz 
sözlerine devamla : "Hasta sekiz gün önce kendini öyle iyi hissetti ki, tek başına bir odada yatmak istemedi. Beş gün önce apatik, sürekli kusmaktan bitmiş bir halde olan hasta, artık sohbet edecek arkadaşlar ariyordu.»

Mikulicz beni genel bir koğuştaki bir hasta yatağının yanına getirdi. Hasta yarı oturur durumda çorba içmekteydi. Her ne kadar yüzü solgunsa da, o açlığa mahkum insanların parşömen yüzüne hiç benzemiyordu.

Mikulicz hastaya dönerek "Bu bay Dr. Hartmann. Sizin ameliyat1nızı duymuş ve sizi bir kez de kendi gözleriyle görmeğe gelmiş» dedi. Bana dönerek : "İște bu da Bayan Helene Heller» diye sundu. Ben : «Ben bayan Hellerr nasılsınız? Ağrınız var mı? Yemek yiyebiliyormusunuz? Kendinizi iyileşmiş hissediyor musunuz?» diye sorunca o gülerek : Evet doktor bey. Kendimi hasta olmadan önceki gibi sağlıklı hissediyorum. Yakında ayağa kalkacağım. Artık hiçbir şikayetim yok» diye cevap verdi. Ona elimi o kadar sevinçle uzattım ki, bana hayretle baktı. Kalbimin ne denli sevinç ve umutla dolduğunu nereden bilebilirdi ki?

Mikulicz beni anatomik preparatların saklandığı bir odaya götürdü. Orada bana Helene Heller'in mide-barsak sisteminden Billroth'un çıkardığı tümörü gösterdi. Susan'ın hayatını mahvedecek düşmanı ilk defa yakından gördüm. Tümörün uzunluğu hemen hemen ondört santimetre kadardı. Mide çıkışını öyle doldurmuştu ki ancak bir tüy kalemin sapı geçebilirdi.

Hemen o akşam Susan'a iki telgraf çektim. Telgraflar umut, güven ve rahatlama dolu sözleri içermekteydi.

Mikulicz bana Billroth'un Susan'ı tedavi ve ameliyat etmeğe hazır olduğunu söyledi. Ama Billroth, benimle her şeyi açık açık konuşmak istiyordu. Yaptığı ilk ameliyatın başarılı olmasına karşın Susan'ın sonucu için kimsenin kesin birşey söyleyemeyeceğinden emin olmamı, bana açıklayacaktı.

Aynı gün dönüş biletimi aldım. Viyana'da bir saat bile zaman kaybetmek istemiyordum. Biran önce gidip, Susan'ı Billroth'a getirmek istiyordum.

Bunun için özel bir tren kaldırmak gerekse de bunu seve seve yapacaktım. Öğleden sonra saat üçte Billroth'un Alserstrasse'deki gör- 
kemli evine gittim. Bu evi Billroth eski Viyana'nm ünlü hekimlerinden biri olan Johanın Peter Frank'tan satınalmıștı.

Billroth, sakallı, iri-sağlam yapılı ve şişmandı. Alman asıllı cerrahların kralı, kendine özgü tartan bir bakışla beni süzdü ve kısa parmaklı, etli ve kuvvetli elini bana uzattı. Alışılmadık açıklıkta mavi gözleri vardı. Kuzeyli olup, doğu denizi kıyısında Rügen'de doğmuş olan ve Zürih'ten Viyana'ya gelmiș bulunan üstadın hemen hemen mahzun bir görünüșü vardı. Fakat bu ciddiyet, kişiliğinin sadece bir yanıydı. Öte yandan ise, kişiliğinde birçok sanatçıda olduğu gibi espri yeteneği ve neşelilik vardı. Fakat, elbette bu bizim ilk yakın karşlaşmamızda neşe ve esprinin yeri yoktu.

Billroth elini muhteşem başına hafif dayamış; gövdesi, hafifçe öne doğru eğilmiş olarak karşımda oturuyordu. Bilimsel titizliği ve sanatçı yapısı ile birçok işte öncülükler yapmış, şimdi de «modern mide cerrahisinin mucidi ve babası" olan bu adam, henüz elliiki yaşındaydı. Her ne kadar şimdi titiz ve sistematik çalışma gösteriyorsa da gençliğinin ataklığını tamamen üzerinden atmıș değildi.

Bana dönerek : «Bay Mikulicz, bana durumunuzu anlattı. Meslektaş olduğumuzdan dolayı hanımınıza böyle yeni ve ağır bir ameliyatı düşünebilmem için, durumu bir de sizden dinlemek isterim" dedi. Sanki ameliyatı kabul etmeyeceği korkumu gözlerimden okumuş gibi bana sıcak kalplilikle baktı ve devam etti. : "Ameliyat yapabilmek için, sonucun iyi olacağına ilişkin biraz şansın olması lazım. Hiçbir şans bulunmadan ameliyat etmek, cerrahinin değerli sanatını kötü yolda kullanmak olur. Şimdi... Durum nedir.?»

Her şeyi anlattım. Duruma tek bir daha iyi gösterici unsur eklemedim. Buna karşın sonunda reddetmedi. «Fakat sizden birşey rica ediyorum. 29 Ocak'ta başardığımız şey beni gurura boğdu. Ama, hala herşeyin böyle sakin gideceğine bir türlü inanamıyorum. Her şey böyle devam etse ve biz mide tümörlerinin ameliyat edilebileceğini kanıtlarsak bile, kötü huylu tümörlerde "nüks» sorunu henüz aydınlatılmış değil. Belki de, biz sadece ölümü geciktirmiş olduk. Ama ne kadar zaman için, onu da bilmiyoruz. Bilim tarihinde sıçramalar yoktur. İleriye doğru büyük bir adım attığımızı hayal edersek, bunu hemen dörtte üçe indirmeğe mecburuz.

Eğer bütün bunları göze alıyorsanız, benden çok şey beklemiyorsanız ve muayene bulguları da izin verirse, eşinize bir girişim yapmaya hazırım». 
O anda, Billroth'un kararını kolaylaştırmak için, herhalde her şeye hazırdım. Viyana'dan dönüşümden birkaç dakika önce Susan'a çektiğim telgraf onun hastalığına karşı kazanacağımız zaferin bir habercisi, içinde Billroth'un çekimserliğinden hiç söz etmeyen bir sevinç çı̆̆lığ gibiydi.

Tabii beni istasyonda karşılamalarını beklemiyordum. Bir fayton tuttum. Kar yağmış ve donmuştu. Atların nalları yeri kavrayamıyordu ama, ben eve faytonla gitmeğe karar verdim.

Arabadan atladım, kapalı bulunca kapıyı kırarcasına çaldım. Sonunda Maria'nın ayak seslerini duyunca, kalbim deli gibi çarpmağa başladı. Ayak sesleri yaklaştı ve nihayet kapı açıldı. Maria'nın solgun yüzünü görünce ve beni görür görmez ağlamağa başlayınca sanki bir el boğazımı sıkıyormuş gibi hissettim. "Karım nerede?» diye bağırdım. Fakat Maria hıçkırıklarla o kadar sarsılmaktaydı ki bir türlü konuşamıyordu. İçimde çok kötü bir şüphenin kabardığını hissettim. Koşarak koridoru geçtim. Odamı da geçerek Susan'la vedalaştığım odanın kapısını açıp durdum.

Susan lapa lapa yağan kara bakan pencerenin altında yatağında yatıyordu. Yüzü çektiği acılardan uzak, en güzel elbisesi giydirilmiş olarak yatıyordu. Sanki derin ve çok sakin bir uykudaydı. Ölmüştü...

Bu benim kaderimin tokatı değil, bugün «Mide cerrahisi» adıyla anılan olayın doğum bildirisidir.

Susan'ın kaderinin bu işe karışması, bazı hastalıkların tedavisi veya hiç olmazsa geçici bir zaman için iyileştirilmesi aşamasına gelen cerrahinin tam bu döneminde Susan'ın hayatının bu hastalıklardan birinden sonra ermesi sonucu olmuştur. Susan'ı ölümünün içimde blraktığı etkileri aşabilmem hemen on yıl sürdü.

Cerrahların büyük buluşları sonucu, zaman zaman cerrah ellerinin «her şeye muktedir» olduğuna inanılan firtınalı on yılları geride bıraktıktan sonra tıp biliminin, bilhassa cerrahinin sınırlarını ve mevcutla yetinilmesi gerektiğini öğrenmek birçok yılımı aldı. Susan'ı kurtaracak anahtarı ellerimde tuttuğuma inandığım bir zamanda onun ölümüne isyanım, yaşamına kendi elleriyle son vermesi karşısındaki şaşkınlığım sonsuzdu. Evde Susan'ın morfin biriktirerek bunlarla daima uykuya dalabileceğini birçok kez düşünüp, onları imha etmemiş olmamdan dolayı kendimi suçlu hissediyordum. Billroth'un ilk kez mide 
rezeksiyonu yapıp «Billroth I ameliyatı» büyük ün kazanmış olduğu hastası Helena Heller'in dört ay sonra öldüğünü duyunca, bu suçluluk duygusu biraz hafifledi. Helena Heller tamamen iyileştikten sonra, tümörün nüksetmesi sonucu ölmüştü. Bu olay, kötü huylu mide tümörlerinde yapılan ameliyatın tedavi sınırlarını göstermişti. Her ne kadar bu sınırlar sonraki on yıllarda bir hayli genişlemişti, ama hiçbir zaman tamamen bertaraf edilmemiști. Billroth 24 Haziran 1883'te ikinci mide ameliyatını yaptı. Fakat hasta öldü. 26 Ocak 1884'te üçüncü vakasını ameliyat etti, ama o da öldü. Bu sonuçlar ızdırabımı biraz azalttı. Demek ki Susan'ın hayatını zorlamak pek bir işe yaramayacaktı.

Ancak, 21 Temmuz 1884'te Rydgier'in yaptığ 1 ameliyat yeniden nüks oluncaya kadar, hastaya iki buçuk yıllık bir ömür bağışladı.

Billroth haklı bir çekimserlik içindeydi. Çünkü "Billroth - I» ameliyatı emin bir ameliyat oluncaya kadar elinde sayısız hasta öldü. Birçok hastada çok genişlemiş tümör "Billıroth - I» ameliyatı ile halledilemiyordu. Çünkü mide ve barsağm büyük bir kısmını çıkarmak gerekiyordu. O zaman da, kalan parçaları yeniden birleştirmek mümkün olmuyordu. 1885 yılına kadar «Billroth - II» diye adlandırılan ve dünyaca meşhur olan ameliyat yöntemini geliştirdi. Bu yöntem de mide çıkışındaki tümör tıpkı Billroth - I de olduğu gibi çıkarılmakta, fakat mide ve barsak kesi yerinden birleştirilmemekte, bu ağılar dikilip kapatılmakta ve midenin kalan kısmı ile barsak, Billroth'un asistanı olan Wölfler'in bulduğu bir yöntemle birleștirilmektedir. 15 Ocak 1885'te Billroth bu ikinci ameliyat yöntemini ilk kez bir insanda uyguladı. Hastası birbuçuk yıl nüks olmadan yaşadı.

Billroth - I ve Billroth - II ameliyatları başlangıçta sadece öldürücü mide kanserine karşı verilen savaşta kullanıldı. Fakat daha sonra midedeki bütün yaralarda, tümörlerde mide cerrahisinin temel ameliyatları olarak kullanıldı ve bu temel üzerinde modifikasyonlar yapılarak gerçek zaferine ulaştı. 